\title{
LINKING WINE CULTURE, IDENTITY, TOURISM AND RURAL DEVELOPMENT IN A DENOMINATION OF ORIGIN TERRITORY (NW OF SPAIN) ${ }^{1}$
}

\author{
Elena De Uña-Álvarez* \\ University of Vigo \\ https://orcid.org/0000-0002-7331-5340 \\ Montserrat Villarino-Pérez** \\ Tudistar Group. Autonomous University of Barcelona \\ https://orcid.org/0000-0002-6154-244X
}

\begin{abstract}
The role played by synergies between wine culture, territorial identity and tourism may be crucial for rural development. This research focuses on the perception and experiences about this topic by the local actors in the territory of the Denomination of Origin Ribeira Sacra (NW Spain). The research relied on twelve in-depth interviews. The wine culture, along with its landscape and heritage, favors the consolidation of tourism strategies. The synergies between the world of wine, identity and tourism generate values that are essential for rural development.
\end{abstract}

Keywords: Designation of Origin; Wine; Landscape; Identity; Rural, Spain.

Fecha de recepción: 15 de mayo de 2018

Fecha de aceptación: 28 de enero de 2019

*History, Art and Geography Department. Geaat Group. University of Vigo. Campus As Lagoas, s/n. 32004 OURENSE (Spain). E-mail: edeuna@uvigo.es

** Collaborating researcher of Tudistar Group. Autonomous University of Barcelona. Plaza de Galicia, 3. 15706 SANTIAGO DE COMPOSTELA (Spain).E-mail: montserrat.villarino@usc.es

1 The development of this research corresponds to the project CSO2016-74861-R «Tourism of interior in Spain: challenges, valuation and strategies before changeable situations and of crisis to stimulate products and tourist destinations. Dynamics of cases» (2017-2019), funded by the Spanish Ministry of Economy and Competitiveness, in compliance with the call for «Research, Development and Innovation» program, targeting «Challenges of Society» (Principal researcher G. Cànoves and A. Blanco, Universitat Autònoma de Barcelona, Spain). 


\section{Enlazando cultura del vino, identidad, turismo y desarrollo rural en un territorio con Denominación de Origen (Noroeste de España)}

\section{RESUMEN}

El papel de las sinergias entre cultura del vino, identidad territorial y turismo puede ser crucial para el desarrollo rural. El enfoque de la investigación considera la percepción y experiencia de los actores locales sobre esta cuestión, en el territorio de la Denominación de Origen Ribeira Sacra (Noroeste de España). La metodología está basada en la realización de entrevistas en profundidad. La cultura del vino, junto con su paisaje y patrimonio, favorece la consolidación de las estrategias turísticas. Las sinergias entre cultura del vino, identidad y turismo generan valores esenciales para el desarrollo rural.

Palabras clave: Denominación de Origen; Vino; Paisaje; Identidad; Rural; España.

\section{INTRODUCTION}

The rural areas of the European Union (EU) covers $85 \%$ of European total surface and are home to more than half of its population, unveiling wide diversity (European Commission, 2018). Some peripheral European rural regions, including most of the rural Spanish areas, have been affected since the 19th century by processes of depopulation and land abandonment (Lasanta et al., 2017). The 2008 global economic recession had high negative impacts in these rural areas which increase their vulnerability face the globalization processes (Capello and Caragliu, 2016). In order to reduce territorial inequalities and foster sustainable development, the EU follows a "new rural development paradigm" (OECD, 2016) thinking that local actors and dynamics can determine the responses of agricultural areas to present-day challenges. The rural development (Van der Ploeg, 2012) is a pillar of the Common Agricultural Policy (CAP), strongly entangled with the protection of the environment for strengthening rural economies and help them to defy the situations of crisis (European Commission, 2010). It is according to the priorities of the 2020 EU Territorial Agenda which encourage planning a development based on local endowments, characteristics and traditions, and consider the participation of local actors as a key factor (European Commission, 2015). The transposition of these European policies in Spain (2014-2020) embraces one National Rural Development Program and seventeen Rural Development Programs in the Autonomous Communities (MAGRAMA, 2016).

This research was focused on the power of wine culture for arrange a territorial identity that found the strategies of development. It was aimed to know the perception, ideas and values of the local actors in a Spanish rural area. What do local actors think about its wine, its landscape, its relationship with territorial identity, tourism and development? According to the research focus, the objectives were to explore the synergies between wine culture, territorial identity and tourism considering their valuation by local actors 
and defining their role in the development strategies; and to analyze the viewpoints and values conveyed by local actors about the role of wine culture in creating a territorial identity. The study area was the territory of the Ribeira Sacra Denomination of Origin, located in northwestern Spain. This Denomination of Origin originated in 1995 with the resurgence of a heroic viticulture on the slopes of a river canyon (Regulatory Council of the Denomination of Origin Ribeira Sacra, 2017), inseparable from the flavor of an ancient landscape and a history of defiance.

\section{THEORETHICAL FRAMEWORK}

The development of agricultural areas involves today new local narratives and discourses. In the emergent 'global countryside' (Woods, 2007) the opportunities to make different outcomes depends on the capacity to value local resources, reorganize strategies and reshape territorial identity (Woods and McDonagh, 2011). In this context, the processes of diversification and integration to improve competitiveness and quality of life hold the territorial identity through several products. Such products have symbolic characteristics and are defined as heritage because they are identity markers "related to a collective social memory" (Bessière, 1998: 26) and play an important role when the tourism is promoted. Deep-rooted in territorial and social signatures, these distinctive products are strategic assets of rural development in European lagging regions (Libery and Kneafsey, 1998; Murdoch et al., 2000). They reflect the symbolic potential of the culture and heritage (Sims, 2009) being attached to the appreciation of the environments that society perceives as traditional and local. But the proliferation of products certifications could be only a form of territorial protectionism rather than an opportunity to strength development (Winter, 2003; Ilbery et al., 2005). The appreciation and function of agro- products linked to a geographical origin also may be adopted or rejected by local communities (Sánchez- Zamora et al., 2014).

Drinks linked to a specific geographical origin and landscapes are increasingly demanded by certain niches markets and consumers (Ilbery et al., 2000). Their qualification labels represent a distinctive social construction designed "to tell the story of the region and offer experiences to citizens" (Horlings and Marsden, 2014: 15). In fact, each wine has its own cultural landscape reflecting the interactions nature-society, and has a symbolic power (Lugeri et al., 2011). The delivery of wine values is interwoven into the native culture, traditions, territory and feelings (UNESCO, 2005); it is created merging the territorial identity, the awareness of local communities as well as the aspirations of consumers and tourists (Brown and Getz, 2005; Rippon, 2014). The wine will be a standard of excellence for the collective identity, a vector for spreading the culture and territorial identity as a shared symbolic system (Elías, 2008 and 2010), including the ethnography, landscape, and its status as a sacred fruit or as the protagonist in the local gastronomy. Certifying the origin of wine has a multidimensional character, which comprises a set of goods which are "glued together by inter-related winescape elements (vineyards, wineries and other physical structures, wines, natural landscape and settings, people and heritage, town (s) and architecture" (Johnson \& Bruwer, 2007: 277). However, although having a Denomination of Origin is important, it is not enough to promote 
rural development if there are no emotions or benefits that generate positive attitudes towards the wine product and its territory enhancing an affective association (Famularo et al., 2010; Mitchell et al., 2012). Furthermore, the growing interest in experiential travel in which the primary attractions are heritage, landscape and wine is an opportunity to increase a product's consumption and sales and favors the knowledge and development of agricultural areas (Getz, 2000). Knowing, enjoying, tasting and establishing social relationships are the main motivations of wine tourists (Alant and Bruwer, 2004; Carmichael, 2005; Bruwer and Alant, 2009; Cànoves and Sushett de Morais, 2011) who seek a pleasant experience in a cultural landscape.

In Spain, wine has taken on an economic, touristic and cultural value capable of boosting agricultural areas, especially if they have a Designation of Origin (DO). Data from the International Organization of Vine and Wine (2016) places Spain in third place in worldwide wine production, with 37.8 million hl, while Italy (48.8M HL) confirmed its first place as a global producer, followed by France $(41.9 \mathrm{M} \mathrm{hl})$. However, the value of wine in Spain goes beyond this market position. Between 2008 and 2016, the Spanish Association of Wine Cities (ACEVIN by its Spanish initials), which manages the Wine Routes of Spain, registered a $43 \%$ increase in the number of wine tourists. The Tourism Institute of Spain estimates an average expenditure of 397.83 euros for wine tourists, compared to the 129 euros spent daily by the general foreign tourist (EGATUR, 2016) and 53 euros by the general tourist Spanish (FAMILITUR, 2016). Spanish wine tourism is linked to natural, rural and cultural tourism and it especially contributes to rural development (Marzo-Navarro and Pedraja-Iglesias, 2009; Frutos Mejías et al., 2012; Plaza Tabasco et al., 2017). The culture of wine is a heritage asset (Institute of Cultural Heritage of Spain, 2016) with 23 high interest areas that continue to maintain vineyard cultivation and their cultural landscapes, among which is the study area of this research.

Territory, landscape and wine culture take part in creating the identity of a destination, which is a key process in developing sustainability and competitiveness strategies that are based on authenticity. This process pertains to different areas where tasting is paramount and, above all, intangible cultural heritage is highly relevant. In the territories designed by a DO, the culture of wine, along with its landscape and heritage, can give meaning to a territorial brand that favors the consolidation of sustainable tourism strategies. The synergies between the world of wine and tourism may generate new economic, touristic and cultural values in rural areas affected by a crisis situation.

\section{METHODOLOGY}

Once was selected, the documentation and statistics of the study area were explored together with a first fieldwork. The documental and bibliographic research included a websites study as well as the information collected from the development rural groups and the local municipalities. The evolution of the conditions for the DO territory was considered mainly in a temporal period close to last crisis. These conditions were characterized using environmental, demographic and socio-economic indicators among plans affecting local dynamics and initiatives, with a special emphasis on the wine qualification. The indicators of the demographic situation (total population, population 
rate of change 2007-2016 and demographic structure by large age groups in the same temporal sequence) and the population activity were elaborated starting from the data provided by the Galician Institute of Statistics (IGE), the Spanish National Institute of Statistics (INE) and Eurostat. Regarding the viticulture data and the promotion of wine culture, the information sources were the Regulatory Board of the Ribeira Sacra Denomination of Origin, the Tourism Consortium and the local associations.

The main local actors were identified by this information and the interaction with local communities during a new fieldwork, throughout a snowball sampling. In order to know the processes and analyze the dynamics inherent to them, assessing their contribution to rural development, the research also relied on twelve in-depth interviews. Two groups of local actors were selected for this task: owners-managers and qualified informants. They included six owners-managers who are involved in processes of territorial revitalization linked to wine culture, and six qualified informants from either the sociocultural or political world. Then, a qualitative research was accomplished. In-depth interviews were selected as an appropriate methodology, since they allow evaluating non-neutral knowledge (Flick, 2002; Pepper and Wildy, 2009; Bernard and Ryan, 2010; Jackson and Mazzei, 2012). Between 2011 and 2012, following the questionnaire available in the publication of Cánoves et al. (2014), were conducted twelve interviews lasting approximately two hours each. The interviewees responded freely to questions. The interviews were recorded digitally for later transcription and analysis. In addition, the interviewer kept small diaries with notes.

The interviews with owners and managers began with four questions about the work project, including the dominant values in decision-making and their degree of satisfaction. It then addressed the opportunities and risks of the territory regarding their economic activity, with fourteen questions about the advantages and disadvantages, innovative potential, their knowledge of other initiatives, relationships with public and/or private institutions, and their evaluation of the project being developed. Finally, ten questions addressed the future prospects of both the labor project and the territory of the DO: possible investments and problems; the state of infrastructures, public services and communications; employment possibilities; primary values of the territory; sense of belonging, and definitions of the distinguishing features of territorial identity.

The interviews with the qualified informants began with four questions about the reasons, motivations, values and satisfaction with their activities. Then, eleven questions requested their opinions about these activities in the DO territory: importance; degree of innovation; agents involved; means of training and promotion; management methods; policies and developmental measures carried out; and defining strategic actions for local improvement. Finally, eight questions dealt with the values and identity of the DO territory, the sense of belonging, the future of the area, the necessary improvements and defining the distinguishing features of the territorial identity.

The transcriptions of the recordings respected the expressions and silences of the people. From readings of the answers, the information was classified according to the objectives of the study. It was analyzed, removing the key concepts and narratives about wine culture, identity, tourism and development. The interpretation of the texts was elaborated considering the dynamics of the DO territory. 


\section{RESULTS}

\subsection{The territory of the Ribeira Sacra DO}

In the interior of the autonomous community of Galicia (Northwest of Spain), the canyons formed by the rivers Miño and Sil offer a singular landscape. The sunny and steep slopes are used to cultivate grapevines on terraces and the quality of the wine is certified by the Ribeira Sacra DO (Figure 1). The territory of the DO includes 20 municipalities spread over $2,523 \mathrm{~km}^{2}$ (8.53\% of the total of Galicia) with a total population of 61,012 inhabitants representing 2.24\% of the total of Galicia (IGE, 2017). Monforte de Lemos (province of Lugo), with 16,335 inhabitants, and Castro Caldelas (province of Ourense), with 610 inhabitants, are the county heads of the DO territory (IGE, 2017).

\section{Figure 1 \\ LOCATION AND TERRITORIAL ORGANIZATION OF THE RIBEIRA SACRA DO}

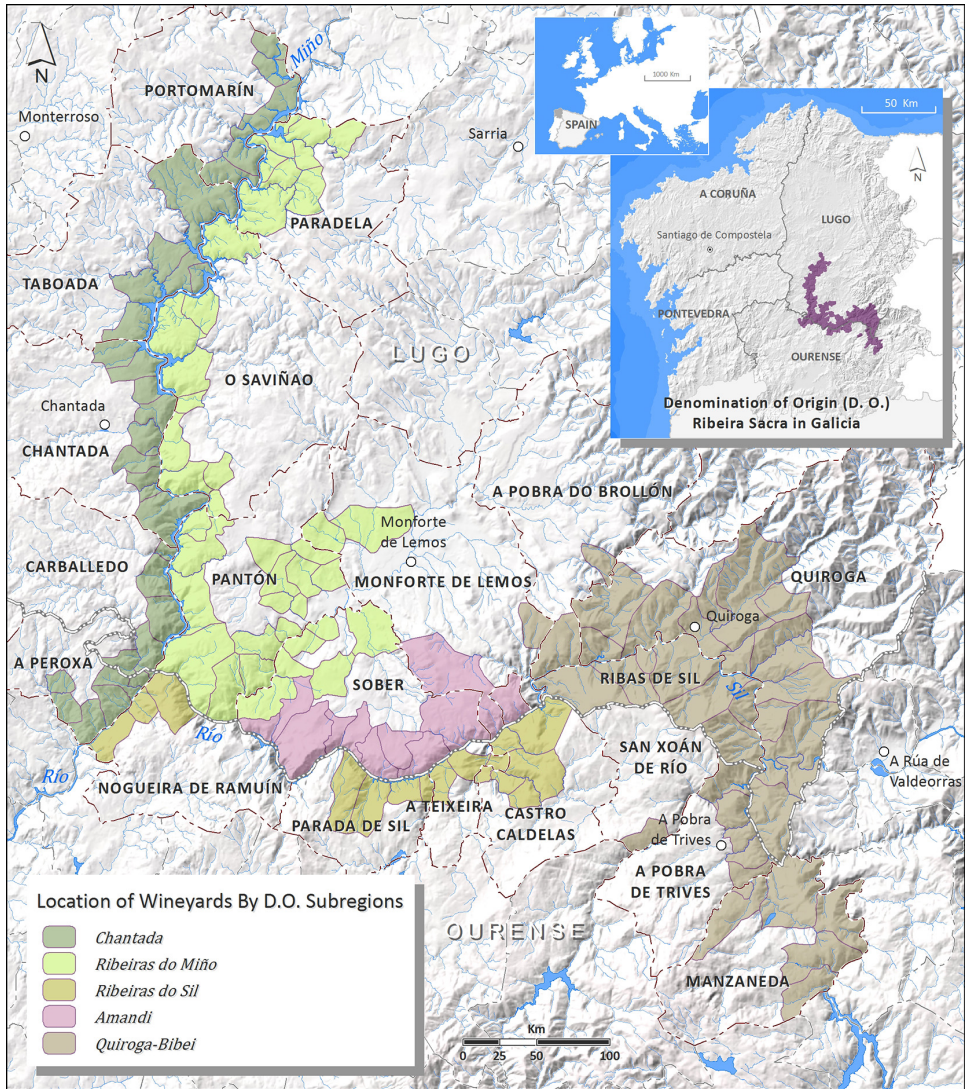

Source: Own elaboration. 
Although the majority of the employed population $(66.78 \%)$ works in the services sector, agricultural activity occupies $14.90 \%$ of it, reflecting the rural nature of the territory. The proportion of the population employed in agricultural activities in RS is much higher than the $6.2 \%$ it represents in Galicia, the $4.2 \%$ in Spain and the $4 \%$ in the European Union. The decline in the total population after the socioeconomic crisis (Table 1) is also much higher than in Galicia, showing a critical situation compared to data from the national and European territory. In the DO territory, the demographic structure by large age groups has not varied substantially between 2007 and 2016 (Table 2), but it highlights the high degree of ageing compared to Galicia, Spain and the European Union.

Table 1

POPULATION RATE OF CHANGE (\%) 2007-2016

\begin{tabular}{|c|c|c|c|}
\hline TERRITORY & Population 2007 & $\begin{array}{c}\text { Population } \\
2016\end{array}$ & $\%$ Change \\
\hline Ribeira Sacra D.O. & 69,246 & 61,012 & -11.89 \\
\hline Galicia & $2,772,533$ & $2,718,525$ & -1.95 \\
\hline Spain & $45,668,938$ & $46,528,618$ & 1.90 \\
\hline European Union (28) & $500,297,033$ & $511,805,088$ & 2.30 \\
\hline
\end{tabular}

Sources: Galician Institute of Statistics (IGE), National Institute of Statistics (INE) and Eurostat (Own elaboration).

Table 2

DEMOGRAPHIC STRUCTURE BY LARGE AGE GROUPS (\%) IN 2007 AND 2016

\begin{tabular}{|c|c|c|c|c|c|c|}
\hline AGE GROUPS & \multicolumn{2}{|c|}{$<16$} & \multicolumn{2}{c|}{$16-64$} & \multicolumn{2}{c|}{$>64$} \\
\hline Territory & 2007 & 2016 & 2007 & 2016 & 2007 & 2016 \\
\hline Ribeira Sacra D.O. & 8.15 & 8.13 & 56.20 & 55.66 & 35.65 & 36.20 \\
\hline Galicia & 12.16 & 12.73 & 66.25 & 62.95 & 21.58 & 24.33 \\
\hline Spain & 14.63 & 15.06 & 68.93 & 65.98 & 16.44 & 18.96 \\
\hline European Union (28) & 15.90 & 15.60 & 67.10 & 65.30 & 17.00 & 19.20 \\
\hline
\end{tabular}

Sources: Galician Institute of Statistics (IGE), National Institute of Statistics (INE) and Eurostat (Own elaboration).

Becoming certified as a wine DO in 1995 was decisive in preserving the traditional landscape and increasing wine production (Table 3). Today it constitutes a hallmark for Ribeira Sacra and its territorial brand of tourism. Enotourism and its associated visits to wineries and vineyards are integrated into activities that are related to the natural, historical, artistic and landscape heritage (Cánoves et al., 2017). Aside from rural tourism, 
which was the primary tourist activity, nature and wine tourism are promoted under the protection of opportunities in the supra-local area (Leader European funds) with a strong boost from the territory's local managers (Rural Development Groups, Tourism Consortium, and Associations).

Table 3

EVOLUTION OF THE VITICULTURE DATA

\begin{tabular}{|c|c|c|c|c|}
\hline Ribeira Sacra D.O. & 1992 & 1996 & 2000 & 2016 \\
\hline Number of wineries & 40 & 55 & 71 & 89 \\
\hline Number of viticulturists & 550 & 1,100 & 2,500 & 2,438 \\
\hline Number of hectares & 300 & 900 & 1,000 & 1,241 \\
\hline Production (thousands of kg) & 350 & 2,187 & 4,533 & 5,585 \\
\hline
\end{tabular}

Source: Regulatory Board of the Ribeira Sacra Denomination of Origin (Own elaboration).

With 3,148,386 liters of wine bottled in 2016, the Wine Center (Monforte de Lemos) promotes the product by proposing a journey through the artistic, historical and natural heritage of wine culture (Figure 2): civil architecture, nature, monasteries, wineries, festivals, traditions and crafts also related to the Camino de Santiago. This center hosts the Wine Club for tasting wines, attending expert conferences and taking courses in tasting and viticulture. Wine is a mobile resource that spreads the territorial identity through fairs in the DO area, with the Wine Fair in the Amandi sub-area having been declared of interest to tourists. RS wine has won several prizes (for example, Small DO, Monovarietals and Catavinum in 2017) in gourmet trade fairs such as the Prowein International Fair and the Gastronomic Forum.

Figure 2

THE WINE CENTER (MONFORTE DE LEMOS, GALICIA, SPAIN)

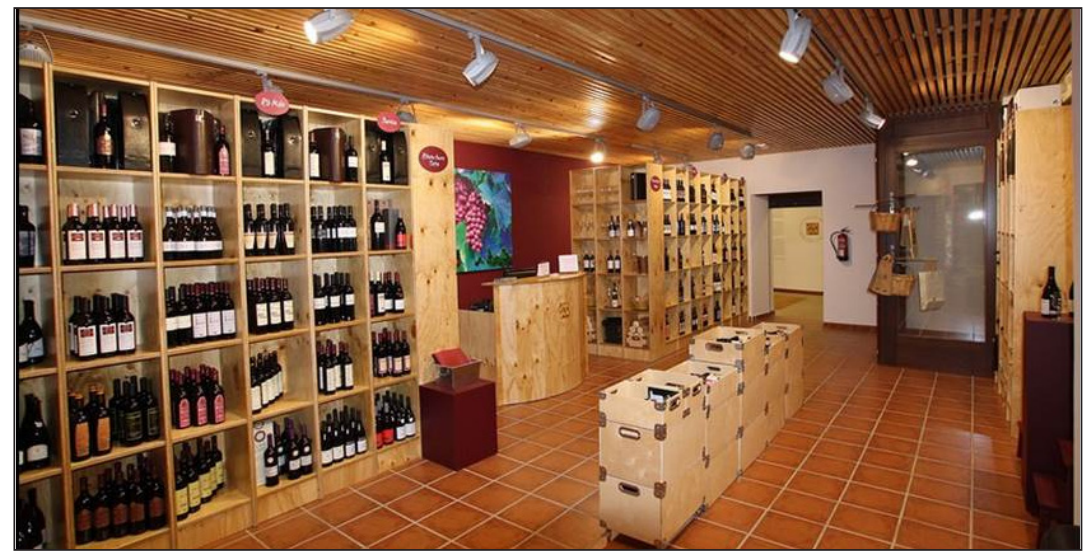

Source: Centro del vino de la Ribeira Sacra (http://www.centrovino-ribeirasacra.com). 


\subsection{Results of the interviews}

After having been declared a DO, which led to modernizing the processes of production, commercialization and distributing the product, viticulture became a key economic resource. The overlap with tourism intensified the economic value of wine, and now this value cannot be understood without referring to other dimensions that link wine to the territory and its landscape. The analysis of the interviews conducted shows this clearly.

\subsubsection{Economic value}

The economic dimension and its importance for the area are indisputable, as indicated by the businessmen, managers and qualified informants.

«The wine is already a driver of the economy, and it's not going to diminish, it will grow stronger». (Owner)

«The wine market is very strong. In fact today there are 100 wineries, a hundred and some wineries, and year after year it gets stronger. It's a product that is getting much stronger». (Manager)

«These wines came to the market with luck. They were already very well positioned, and they have been being exported and have made Ribeira Sacra very well known». (Manager)

The economic value of wine is related to innovations in the production process, which allowed producing a profitable commodity that adapted to the demand. In innovation, foreign businessmen played an important role, as reflected in the opinions of several informants.

«That winery, as it is the first, I do not know exactly what led the lord of the estate to do it, but he was dedicated to wines and I think the wine [...] because the Ribeira Sacra wine was a famous wine, and then he had many wineries in the Ribeiro [another DO in Galicia], then saw the possibilities, and decided to buy wine here, vineyards, open the winery in the Rectoral and of course, I think that it was a fundamentally economic desire». (Qualified Informant)

«The profile of the landowning farmer has been evolving. The liberal professional or the one who had a business that has allowed him to invest, improve the quality, and reached people in the urban world and other sectors. The Riveras, we have a business with Estrella de Galicia breweries, they get involved in this, where there is land, and they make a good wine: they get excited, they buy the first vineyards, they buy the second ones, they make a good winery and dedicate themselves to it. [...] So people from the industry are getting into it because they see it as an investment. Or other business people. The upper middle class, who are saying, "Ah! This is an attractive business». (Owner)

\subsubsection{Touristic value}

The tourist industry joined winemaking, and the synergies between the two became enhanced, an aspect that the informants emphasize unequivocally.

«In wine, we are involved with the issue of the wine route. Fully invested. A lot of work is also being done. An association was created to shape the character of the wine route, with the Regulatory Council getting involved, with the Consortium involved, the 
local businesses, some of the Councils, someone from every entity that can get involved in representing it. And now the establishments are being certified, not just the wineries but the accommodations, restaurants and other establishments. The efforts are not so much to homogenize them as to endow them with more enological themes». (Manager)

«Yes it is an attraction that very much complements tourism. It is an industry (that of wine), but it goes tourism. It complements it very much». (Manager)

Modernizing viticulture and associating it with tourism, developing a global tourism product, these had highly important consequences: the dissemination of this rural interior territory via the wine brand, as reflected in the opinion of the informants.

«We have to realize that the theme of wine was the best letter of introduction for Ribeira Sacra. In terms of tourism, the Ribeira Sacra is what it is today largely because of wine. The regulatory council, which created a brand in 1996, the very same brand design that we use. We try to maintain a strong link with wine and tourism. In fact, we share a web page, and I think that this has contributed to a lot of the success of Ribeira Sacra». (Manager)

However, that brand that was created by the synergies between the worlds of wine and tourism is much more broadly and more profoundly substantive, as much to outsiders as to - above all - the population. This is clearly stated by an informant.

«What is the Ribeira Sacra? And everyone responded to me with the same answer: a wine brand, a wine brand, because it was the first thing that most people in Ribeira Sacra knew. They knew wine. Then they began to know that there was a cultural background, a history behind it, a monastic history and such, but first a history of wine. They said a wine brand». (Qualified informant)

The success of the DO destination goes beyond viticulture and wine tourism, because it incorporates tangible and intangible elements that constitute the cultural heritage. In this way, wine is not only the product but the way of life and tradition; it is a link between a past that is reflected in the images of medieval sculpture used by the DO's Regulatory Council and a future to which it contributes value and justified singularity in a multidimensional environment.

«The country folk liked wine culture, to talk about the wine, taking care of it in a certain way... in a very traditional way... they spoke religiously, with a passion close to religious [...]. Of course, they innovated [the traditional farmers] the process a lot, because they went from medieval to modern processes in a very short period of time. They were very fond of the wine culture, but they lived it as medieval, heroic labors». (Owner)

\subsubsection{Cultural value}

They talk of heroic viticulture because of the difficulty of growing on steep slopes (Figure 3). That tradition of constructing and conserving terraces is part of the cultural heritage in the DO territory. And wine is linked to a way of life, a landscape and a specific cultural heritage that gives rise to activities, rhythms and key experiences in offering experiential travel. One of the informants summarizes this value in the following paragraph from his interview:

«It is the product that you live, that is, the work in the vineyard, the work that is done throughout the year, the life that somewhat follows the pace of the work that you have 
to do. You have to do the pruning, you have to make... the sulfite of the vine for certain diseases you have, you have to do the harvest, you have to make the wine, you have to make the brandy, you have to do the wine festival, you have to taste the new wine, and everything around that is a way of life, a culture». (Qualified informant)

Figure 3

THE CULTURAL LANDSCAPE

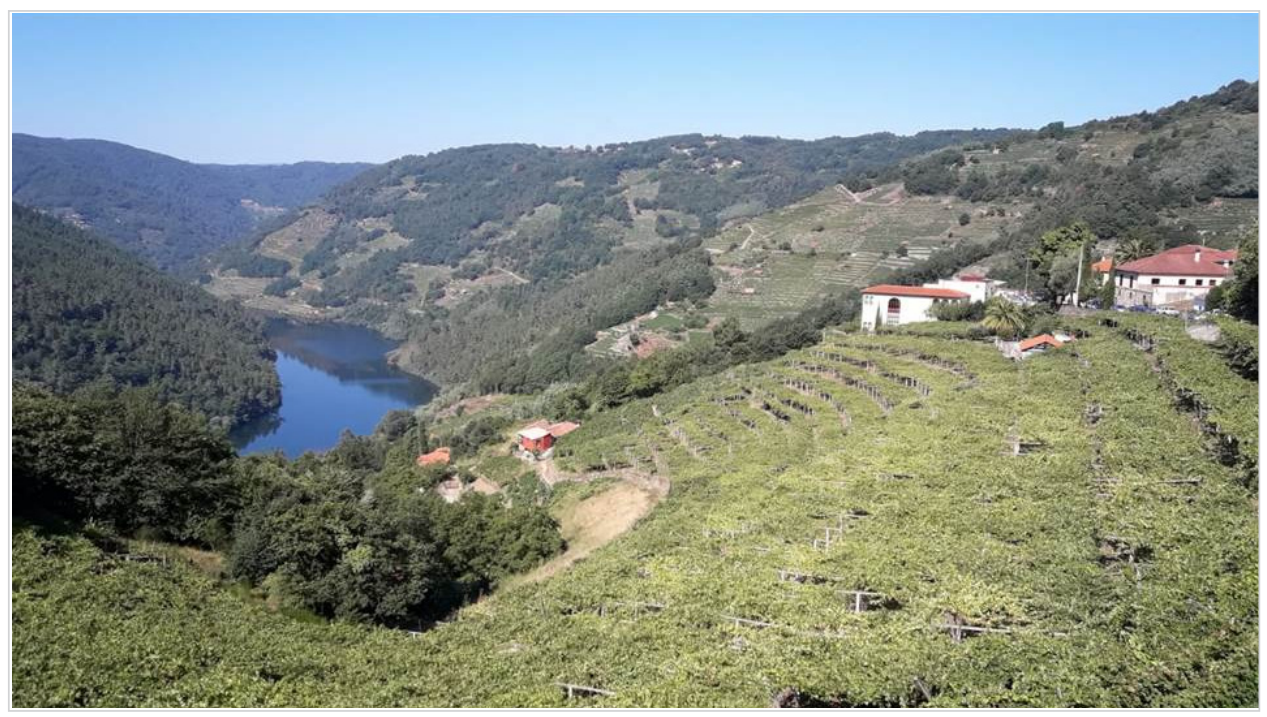

Source: Own elaboration.

All informants highlight aspects that transcend economic value. It is the intangible elements that have laid the foundations of a tourist product within the cultural landscape, which in turn has allowed the image of the territory to spread abroad while at the same time generating an identity. The importance of these processes is evident in the words of an inhabitant.

«Well, as I am a huge fan, I believe we're in an area that has a lot of things, that this became depopulated but it was important, and that the potential has always been there and is resurfacing. Here we have the intersection of three factors. There is nature, which is a powerful nature, among the most powerful that there can be. There is the cultural factor: all the remains left behind by the world of hermits and the monastic world. Also the manor house architecture, which was important, and along those lines there are the architectural remains, which is important. It was lost but was always there, and you can try to put a value on it but it is very important. There are cultures like that of the wine». (Owner)

In summary, the responses of the interviewees to questions about the perceived image of the DO territory are very telling. These answers show that the main features of territorial identity are related to five components: wine, vineyards and terraces (wine culture); forests, 
greenery, nature and rivers (natural landscape heritage); monasteries, churches and country houses (cultural landscape heritage); monuments, landscape and singular accommodations (tourism); silence, tranquility, aesthetic, sensations, disconnecting (emotions and feelings of well-being emerging from the synergies between wine culture, territory and landscape).

\section{DISCUSSION}

Rural development involves material and immaterial elements, social and political entities, new horizons and local strategies. Many of answers refer to a change from a traditional wine culture to a modernized and global wine culture, focused on wine tourism. In this transition the local stakeholders are more and more motivated to engage in protection and valuation of wine culture as a key development factor. There is awareness on the importance of the wine socio-economic value to defy crisis since it was certified by a DO, also revealed by other economic restructuring processes which influenced positively rural development (Aguilar Criado and Lozano, 2008). The ideas of the local stakeholders reflect a social construction linking the socio-economic value of wine to endogenous development. This process, stimulated by the DO Council, is founded on down-top strategies and involve private and public interests driving economy in the phase of wine post-qualification. The couple of wine and territorial identity, as pointed Tregear et al. (2007) is the basis of value generation. Tradition, heritage, wine culture and local identity are perceived as the pillars of development.

Regarding the models of engagement face globalization in European rural regions (Woods, 2013) the conditions of the Ribeira Sacra DO territory embraces re-localizers (that renewal local markets within the region) and niche innovators (moving from local to international markets). Both models manage wine production and landscape as distinctive local resources and, despite constrains by structural factors, local stakeholders perceive the opportunities to strength development. The economic and cultural values of wine are connected by practices which understand the potential of wine culture to resonate with history and look forward towards the future, including the need of external recognition (San Eugenio et al., 2017). This perspective show that exist a resurfacing potential of wine where innovation lives with tradition and according to Maye et al. (2007) producers, suppliers and consumers should not be considered as separated entities. However, the absence of an alternative/conventional dualism in the production-consumption of wine, do not exclude risks. Although the answers of interviews addressed an economy based on wine values more than wine production volume, the DO labelling standards, the orientation to upper middle class and the involvement of external business breweries could generate a process of territorial appropriation; and the farmers outside the wine segment could be forgotten in this process. Aguilar Criado et al. (2011) illustrated these aspects in the rural development strategies of Spain and Brasil. In the same way, Overton and Murray (2011) studied the influence of downscale and upscale processes in the territory appropriation and configuration of hybrid rural identities from the wine industry. Rainer (2016) postulate that the reconstitution of rural land use defines a constructing globalized spaces of tourism where viticulture and touristic projects go hand in hand. The DO play a key role in transforming the Spanish wine sector (Esteban Rodríguez and Climent López, 2017) 
but there are controversies on its symbolic imaginaries of quality. Alonso González and Parga Dans (2018) mention the wine homogenization caused by the regulatory boards of Spanish DO, connected to the power of large companies, the property concentration and the falling grape prices; and explain the situation of peripheral agricultural areas as a resistance response through a social movement of reawakening in wine culture that revitalized the terroir-oriented products. The Ribeira Sacra DO is jointed to this movement and tries to reinforce its territorial identity in the global world around tradition and innovation.

The results from interviews expose that the cultural landscape and its intangible values are highly relevant in this process. Both components have been gradually shared by local community. Following the Convention for Safeguarding Intangible Cultural Heritage (UNESCO, 2003) and the National Plan for Safeguarding the Intangible Cultural Heritage of Spain (Government of Spain, 2016) these conditions remark that local communities could play a key role in the production, safeguarding, maintenance and re-creation of its heritage, helping to promote development. The Cultural Landscape of Ribeira Sacra belongs to the World Heritage indicative list since 1996 and currently is an iconic element for tourism. This landscape of vineyards is promoted as the taste of a peculiar land, enhancing wine economy, culture, identity and tourism. It implies a social negotiation where discourses and practices are continuously adjusted (Sims, 2010). Additionally, the changing interest in wine as a product towards wine as a cultural experience drives the role of wine tourism for the strategies of development.

This change was initiated in Spain and Galicia with the transformation of the rural tourism. The wine routes on offer as well as the festivals and events (e.g. Prat and Cànoves, 2014; Martínez-Puche and Morales Yago, 2016) increased the motivations to know the wine culture. The development of wine tourism centers on recovering the traditions and symbolic world of wine. To enhance an affective association whit a wine-destination, diverse resources and experiences are interconnected in a way that transcends the tangible components. Thus the outstanding values of the Ribeira Sacra landscape of vineyards, an expression of the local memory, conceptualize its function as a territorial and touristic resource; at the same time they contribute to the dissemination of its territorial identity in the local-global interface. Similar conditions reveal the functions of vineyard landscape in the Canary Islands (Spain) as a key resource for rural development (Hernández et al., 2017).

The changes engage more than the wine product (Winkler and Nicholas, 2016) leads to the interaction of values that are aesthetic (a singular landscape), patrimonial (heritage and legacy), educational (learning aspects), recreational (fun, physical and sensory), symbolic and spiritual. Thereby the five components of territorial identity, previously defined from the interviews, merge values which represent a particular outlook on wine culture within the framework of rural development.

\section{CONCLUSIONS}

The DO territory integrates a unique landscape of vineyards, a historical legacy and its own way of life. The Ribeira Sacra has a territorial identity deeply founded on the values of wine culture which are essential for its development. This agricultural area has taken great leaps toward adaptation, adjustment and innovation that are strongly linked to 
a territorial brand. It integrates the socio-economic, touristic and cultural values of wine such as uncover the results of the interviews. Moreover, it offers a tourist product that has adjusted to the multifaceted demand: wine tourism and all its associated activities, nature, culture and, inherent to all of them, experiential travel.

Wine culture arose in the DO territory with the reorganization of the wine product, specifically by preserving its traditional farming landscape while expanding the tourism offer (which initially focused on rural tourism). With the growing awareness and share of the importance of patrimonial goods, wine culture and landscape incorporate a wide range of intangible values. The configuration of a territorial brand progressively generated a territorial identity (related to the culture and landscape of wine), one that is recognized and has spread abroad to help shape the image of the rural area as well as its attraction as touristic destination. The involvement of public and private interests was very fruitful: the interior was improved in terms of infrastructure, activities and business opportunities; while the image was carried abroad through promotion and participation of the wine in different competitions and events.

Tourism's ability to generate synergies that contribute to sustainable and competitive rural development depends to a large extent on proposals for multipurpose activities. In this process, the initiatives for restructuring and innovation are projected in a brand image and rely on the fundamental the support of both the administration and social participation (public and/or private). The Ribeira Sacra is an inland territory that has undergone a process of restructuring and reinvention: wine production was modernized and tourism activities were initiated; with the support of the European, regional and local administration as well as the local society, both initiatives came together to create and continuously renovate an offer of tourism linked to wine culture and the unique landscape. A future research will allow the follow-up of these processes.

\section{REFERENCES}

ACEVIN (2016): Informe anual sobre las visitas a bodegas y museos del vino, producto Rutas del Vino de España. Available in http://www.acevin.es (Accessed 10 January 2018)

AGUILAR CRIADO, E. AND LOZANO, L. (2008): «El territorio y las producciones de calidad como factor de desarrollo sostenible en el medio rural», in Agricultura Familiar en España 2008. Madrid, Fundación de Estudios Rurales, pp. 170-173.

AGUILAR CRIADO, E., SACCO DOS ANJOS, F. AND VELLEDA, N. (2011): «Productos locales, calidad y diversificación: nuevas estrategias de desarrollo en el mundo rural de España y Brasil», Estudios Sociológicos, n 29, pp.189-214.

ALANT, K. AND BRUWER, J. (2004): «Wine tourism behaviour in the context of a motivational framework for wine regions and cellar doors», Journal of Wine Research, vol. 15 (1), pp. 27-37.

ALONSO GONZÁLEZ, P. and PARGA DANS, E. (2018): «The 'terroirist' social movement: The reawakening of wine culture in Spain», Journal of Rural Studies, vol. 61, pp. 184-196.

BERNARD, H. R. AND RYAN, G.W. (2010): Analyzing qualitative data: Systematic approaches. London, Sage. 
BESSIÈRE, J. (1998): «Local Development and Heritage: Traditional Food and Cuisine as Tourist Attractions in Rural Areas», Sociologia Ruralis, vol. 38 (1), pp. 21-34.

BROWN, G. AND GETZ, D. (2005): «Linking Wine Preferences to the Choice of Wine Tourism Destinations», Journal of Travel Research, vol. 43 (3), pp. 266-276.

BRUWER, J. AND ALANT, J. (2009): «The hedonic nature of wine tourism consumption: an experiential view», International Journal of Wine Business Research, 21 (3), pp. 235-257.

CÀNOVES, G. and SUSHETT DE MORAIS, R. (2011): «New forms of tourism in Spain: wine, gastronomic and rural tourism» in Tourism and agriculture: New geographies of consumption, production and rural restructuring. London, Routledge, pp. 205-219.

CÁNOVES, G., VILLARINO, M., BLANCO-ROMERO, A., DE UÑA, E. and ESPEJO, C. (Ed.) (2014): Turismo de interior: renovarse o morir. Valencia, PUV, Colección Desarrollo Territorial, 12.

CÁNOVES, G., BLANCO-ROMERO, A., PRAT, J.M. and VILlARINO, M. (Ed.) (2017): Turismo de interior en España. Productos y dinámicas territoriales. Valencia, PUV, Colección Desarrollo Territorial, 19.

CAPELLO, R. and CARAGLIU, A. (2016): «After crisis scenarios for Europe: alternative evolutions of structural adjustments», Cambridge Journal of Regions, Economy and Society, vol. 9 (1), pp. 81-101.

CARMICHAEL, B. (2005): «Understanding the wine tourism experience for winery visitors in the Niagara region, Ontario, Canada», Tourism Geographies, vol. 7 (2), pp. $185-204$.

ELÍAS, L. V. (2008): «Paisaje del viñedo, patrimonio y recurso», Pasos, vol. 6 (2), pp. 137-158.

ELÍAS, L. V. (2010): «Intangible heritage of the wine», Quaderns de la Mediterrània, vol. 13 , pp. $65-75$.

ESTEBAN RODRÍGUEZ, S. AND CLIMENT LÓPEZ, E. (2017): «Los mundos de producción de las denominaciones de origen protegidas del vino en España», Economía Agraria y Recursos Naturales, vol. 17 (1), pp. 101-125.

EUROPEAN COMMISSION (2010): The CAP towards 2020: Meeting the food, natural resources and territorial challenges of the future. Available in http://eurlex.europa.eu (Accessed 23 June 2018)

EUROPEAN COMMISSION (2015): Territorial Agenda 2020 put in practice. Luxembourg, Publications Office of the European Union.

EUROPEAN COMMISSION (2018): Rural Areas and the primary sector in the EU. Available in https:/ec.europa.eu/agriculture/sites/agriculture/files/statistics/facts-figures/ eu-rural-areas-primary-sector.pdf (Accessed 23 June 2018)

EUROSTAT (2017): European statistics. Available in https://ec europa.eu/eurostat (Accessed 20 October 2017)

FAMULARO, B.; BRUWER, J. and LI, E. (2010): «Region of origin as choice factor: wine knowledge and wine tourism involvement influence», International Journal of Wine Business Research, vol. 22 (4), pp. 362-385.

FLICK, U. (2002): An Introduction to Qualitative Research. London, Sage. 
FRUTOS MEJÍAS, L. M., Castelló Puig, A., Hernández Navarro, M.L., Loscertales Palomar, B., Rubio Terrado, P. and Ruiz Budria, E. (2012): «El espacio vitivinícola aragonés como paisaje cultural y factor de desarrollo», Geographicalia, no 62, pp. 5-34.

GETZ, D. (2000): Explore Wine Tourism. New York, Cognizant.

GOVERNMENT OF SPAIN (2016): National Plan for Safeguarding the Intangible Cultural Heritage of Spain. Available in http://www.mecd.gob.es/planes-nacionales/planesnacionales/salvaguardia-patrimonio-cultural-inmaterial/programas-y-lineas-actuacion. html (Accessed 18 December 2017)

HERNÁNDEZ, S., GONZÁLEZ MORALES, A. AND OJEDA, A. (2017): «El paisaje vinícola como recurso turístico y territorial en Lanzarote (Canarias, España)», Eria, 37(3), pp. 321-334.

HORLINGS, L.G. and MARSDEN, T.K. 2014): «Exploring the 'New Rural Paradigm' in Europe: Eco-economic strategies as a counterforce to the global competitiveness agenda», European Urban and Regional Studies, vol. 21 (1), pp. 4-20.

IGE (2016): Open data of the Galician Statistical Institute. Available in https://www.ige. eu/web/index.jsp?paxina $=001 \&$ idioma $=$ gl (Accessed 20 October 2017)

ILBERY, B., KNEAFSEY, M. and BAMFORD, M. (2000): «Protecting and promoting regional speciality food and drink products in the European Union», Outlook on Agriculture, vol. 29 (1), pp. 31-37.

ILBERY, B., MORRIS, C., BULLER, H., Maye, D. and KNEAFSEY, M. (2005): «Product, Process and Place: An Examination of Food Marketing and Labelling Schemes in Europe and North America», European Urban and Regional Studies, vol. 12 (2), pp. 116-132.

INE (2016): Open data of the National Statistical Institute of Spain. Available in https:// www.ine.es/ (Accessed 20 October 2017)

INSTITUTE OF CULTURAL HERITAGE OF SPAIN (2016): Atlas del Cultivo Tradicional del viñedo y de sus paisajes singulares. Available in http://ipce.mcu.es/difusion/ publicaciones/monografias.html (Accessed 10 January 2018)

INTERNATIONAL ORGANIZATION OF VINE AND WINE (2017): Databases and Statistics. Available in http://www.oiv.int/es/bases-de-datos-y-estadisticas (Accessed 10 January 2018)

JACKSON, A.Y. and MAZZEI, L.A. (2012: Thinking with theory in qualitative research: Viewing data across multiple perspectives. London, Routledge.

JOHNSON, R., and BRUWER, J. (2007): «Regional brand image and perceived wine quality: the consumer perspective», International Journal of Wine Business Research, vol. 19 (4), pp. 276-297.

LASANTA, T., ARNÁEZ, J., PASCUAL, N.E., RUIZ-FLAÑO, P., ERREA, M.P. and LANA-RENAULT, N. (2017): «Space-time processes and drivers of land abandonment in Europe», Catena, vol. 149, pp. 810-823.

LIBERY, B., and KNEAFSEY, M. (1998): «Product and Place. Promoting Quality Products and Services in the Lagging Rural Regions of the European Union», European Urban and Regional Studies, vol. 5 (4), pp. 329-341.

LUGERI, F.R., AMADIO, V., BAGNAIA, R., CARDILLO, A. and LUGERI, N. (2011): «Landscapes and Wine Production Areas: A Geomorphological Heritage», Geoheritage, vol. 3 (3), pp. 221-232. 
MAGRAMA (2016): Marco general para la aplicación de la política de desarrollo rural 2014-2020 en España. Madrid, Publicaciones del Ministerio de Agricultura, Alimentación y Medio Ambiente.

MARTÍNEZ-PUCHE, A. and MORALES YAGO, F.J. (2016): «El vino como recurso turístico para el fomento del desarrollo local. Una oportunidad para las comarcas del Vinalopó (Alicante) y el altiplano Yecla-Jumilla (Murcia)», Cuadernos de Turismo, $\mathrm{n}^{\circ}$ 38, pp. 263-295.

MARZO-NAVARRO, M., and PEDRAJA-IGLESIAS, M. (2009): «Wine tourism development from the perspective of the potential tourist in Spain», International Journal of Contemporary Hospitality Management, vol. 21 (7), pp. 816-835.

MAYE, D., HOLLOWAY, L. and KNEAFSEY, M. (Ed.) (2007): Alternative Food Geographies. Oxford, Emerald.

MITCHELL, R., CHARTERS, S. and ALBRECHT, J. N. (2012): «Cultural systems and the wine tourism product», Annals of Tourism Research, vol. 39 (1), pp. 311-335.

MURDOCH, J., MARSDEN, T.K. and BANKS, J. (2000): «Quality, Nature and Embeddedness: Some Theoretical Considerations in the Context of the Food Sector», Economic Geography, vol. 76 (2), pp. 107-125.

OECD (2016): A New Rural Development Paradigm for the 21st Century: A Toolkit for Developing Countries. Paris, OECD Publishing.

OVERTON, J. and MURRAY, W.E. (2011): «Playing the scales: Regional transformations and the differentiation of rural space in the Chilean wine industry», Journal of Rural Studies, vol. 27 (1), 63-72.

PEPPER, C. and WILDY, H. (2009): «Using narratives as a research strategy», Qualitative Research Journal, vol. 9 (2), pp. 18-26.

PLAZA TABASCO, J. J., CAÑIZARES RUIZ, M.C. and RUIZ PULPÓN, A.R. (2017): «Patrimonio, Viñedo y Turismo: recursos específicos para la innovación y el desarrollo territorial de Castilla-La Mancha», Cuadernos de Turismo, no 40, pp. 547-571.

PRAT FORGA, J. M., and CÀNOVES, G. (2014): «Las rutas del vino del Empordà y del Priorat y su dinámica relacional. Dos destinos con diferente grado de desarrollo del turismo enológico y una dinámica relacional similar», Estudios Geográficos, no 277 , pp. 683-705.

RAINER, G. (2016): «The making of the 'world's highest wine region': Globalization and viticulture restructuring in Salta (NW Argentina)», Erdkunde, vol. 70 (3), pp. 255-269.

REGULATORY COUNCIL OF THE DENOMINATION OF ORIGIN RIBEIRA SACRA (2017): The taste of a land. Available in http://ribeirasacra.org/catalogos/en (Accessed 26 November 2017)

RIPPON, M. J. (2014): «What is geography of Geographical Indications? Place, production methods and Protected Food Names», Area, vol. 46 (2), pp. 154-162.

SAN EUGENIO VELA, J. DE, NOGUÉ, J. and GOVERS, R. (2017): «Visual landscape as a key element of place branding», Journal of Place Management and Development, vol.10 (1), pp. 23-44.

SÁNCHEZ-ZAMORA, P., GALLARDO-COBOS, R. and CEÑA-DELGADO, F. (2014): «Rural areas face the economic crisis: Analyzing the determinants of successful territorial dynamics», Journal of Rural Studies., vol. 35, pp. 11-25. 
SIMS, R. (2009): «Food, place and authenticity: local food and the sustainable tourism experience», Journal of Sustainable Tourism, vol. 17 (3), pp. 321-336.

SIMS, R. (2010): «Putting place on the menu: The negotiation of locality in UK food tourism, from production to consumption», Journal of Rural Studies, vol. 26 (2), pp. 105-115.

TOURISM INSTITUTE OF SPAIN (2016): Encuesta de gasto turístico de los visitantes no residentes en España EGATUR. Available in http://estadisticas.tourspain.es/es-es/ estadisticas/egatur/paginas/default.aspx (Accessed 10 January 2018)

TOURISM INSTITUTE OF SPAIN (2016): Encuesta de movimientos turísticos de los españoles FAMILITUR. Available in http://estadisticas.tourspain.es/es-es/estadisticas/ familitur/paginas/default.aspx (Accessed 10 January 2018)

TREGEAR, A., ARFINI, F., BELLETTI, G. and MARESCOTTI, A. (2007): «Regional foods and rural development: The role of product qualification», Journal of Rural Studies, vol. 23 (1), pp. 12-22.

UNESCO (2003): Convention for Safeguarding Intangible Cultural Heritage. Available in http://unesdoc.unesco.org/images/0013/001325/132540e.pdf (Accessed 25 November 2017)

UNESCO (2005): Convention on the Protection and Promotion of the Diversity of Cultural Expressions. Available in http://www.unesco.org/new/es/culture/themes/culturaldiversity/cultural-expressions/the-convention/convention-text (Accessed 25 November 2017)

VAN DER PLOEG, J. D. (2012): Rural Development and territorial cohesion in the new CAP. Available in http://www.europarl.europa.eu/thinktank/en/document. html?reference=IPOL-AGRI_NT(2012)474529 (Accessed 17 January 2018)

WINKLER, K. J., and NICHOLAS, K.A. (2016): «More than wine: Cultural ecosystem services in vineyard landscapes in England and California», Ecological Economics, vol. 124, pp. 86-98.

WINTER, M. (2003): «Embeddedness, the new food economy and defensive localism», Journal of Rural Studies, vol. 19 (1), pp. 23-32.

WOODS, M. (2007): «Engaging the global countryside: globalization, hybridity and the reconstitution of rural place», Progress in Human Geography, vol. 31 (4), pp. 485-507.

WOODS, M. and MCDONAGH, J. (2011): «Rural Europe and the World: Globalization and rural development», European Countryside, vol. 3 (3), pp. 153-163.

WOODS, M. (2013):« Regions Engaging Globalization: A Typology of Regional Responses in Rural Europe», Journal of Rural and Community Development, vol. 8 (3), pp. 113-126. 